carbon, and zinc or cadmium, with the carbon positive. The spectra are shown in Fig. 1. The cadmium arc shows the emission maximum at 2212 but the zinc are does not show a corresponding maximum at 2060 . This failure of 2060 is probably not due to insufficient vapour pressure of zinc in the arc since the reversals of the zine and cadmium resonance lines are approximately equal in width, and the intensity of $B$ and $C$ relative to the resonance

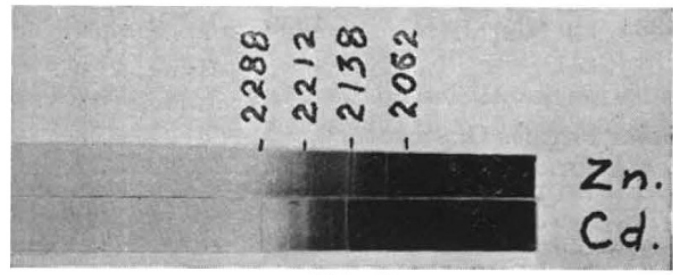

FIG. 1.

lines in absorption is about the same for zinc and cadmium. This observation shows that conditions in the arc are not favourable for emission of band $B$ of zinc although they still may be for $B$ of cadmium. This, however, again indicates that the source of the emission maximum at 2212 in the cadmium are is an impurity.

University of Wisconsin.

J. G. Winans Dec. 22, 1934.

S. W. Cram.

1 J. K. Robertson, Phil. Mag., 14, 795; 1932 . See also NATure, 135, 308, Feb. 23, 1935.

S. W. Cram, Phys. Rev., 46, 205 ; 1934.

\section{Deamination in Virus-infected Plants}

BONCQUET $^{1}$ noticed increased production of ammonia in curly top of beets and in tobacco mosaic and traced it to the presence of denitrifying organisms occurring in association with the diseased plants. Jodidi and co-workers observed similar increase in spinach blight ${ }^{2}$, spinach mosaic ${ }^{3}$ and cabbage mosaic ${ }^{4}$ and attributed it to denitrification since there was diminution in total nitrogen. The latter authors indicated the possible formation of hydroxy acids, but did not study the related acid metabolism.

In the course of an inquiry on the mechanism of increased formation of ammonia in spiked sandal, I noted distinct increase in hydroxy acids, especially malic, in the earlier stages. In the more advanced condition, succinic acid was found to be present in the diseased tissues while it was entirely absent from the healthy ones. These observations having suggested the presence of an active deaminase in infected plants, a series of quantitative studies were carried out, adopting the method of Kisch ${ }^{5}$.

The following were some of the results obtained:

\begin{tabular}{|c|c|c|c|c|}
\hline \multirow[t]{2}{*}{$\underset{\text { hours }}{\text { Time in }}$} & \multicolumn{2}{|c|}{$\begin{array}{c}\text { Ammonia (in c.c. } N / 50 \text { ) } \\
\text { produced by } 1 \mathrm{gm} \text {. of } \\
\text { leaf powder }\end{array}$} & \multicolumn{2}{|c|}{$\begin{array}{c}\text { Carbon dioxide (in c.c. } \\
N / 50 \text { ) produced by } 1 \mathrm{gm} . \\
\text { of leaf powder }\end{array}$} \\
\hline & Healthy & Spiked & Healthy & Spiked \\
\hline $\begin{array}{r}1 \\
4 \\
8 \\
14\end{array}$ & $\begin{array}{l}0.2 \\
0.5 \\
0.8 \\
1.2\end{array}$ & $\begin{array}{l}0.8 \\
2 \cdot 7 \\
5 \cdot 8 \\
9 \cdot 2\end{array}$ & $\begin{array}{l}0 \cdot 8 \\
2 \cdot 1 \\
3 \cdot 4 \\
5 \cdot 1\end{array}$ & $\begin{array}{r}1 \cdot 4 \\
4 \cdot 7 \\
9 \cdot 6 \\
16 \cdot 8\end{array}$ \\
\hline
\end{tabular}

It is clear from the above that the increased production of ammonia is due to greater oxidative deamination in the diseased tissues. Further work on these and other aspects is in progress and will be published shortly in the Journal of the Indian Institute of Science.

\author{
A. V. Varadaraja Iyengar. \\ Department of Biochemistry, \\ Indian Institute of Science, \\ Bangalore. \\ Dec. 22, 1934. \\ 1 J. Amer. Chem. Soc., 38, 2572; 1916. \\ J. Agric. Re8., 15, 385; 1918. \\ J. Amer. Chem. Soc., 42, 1061; 1920. \\ ' Fermentforschung, 13, 433; 1932.
}

\section{Interconvertibility of Glucose and Fructose in Plant Tissue}

IN a recent paper from this laboratory ${ }^{1}$ it was shown that sucrose is formed both from glucose and from fructose when starch-depleted leaves of red clover or wheat plants are placed in 10 per cent solutions of these hexose sugars in the dark. This result was explained by assuming that glucose and fructose are transformed into each other in plant tissue.

Continued research has now confirmed the above assumption. The experiments were made with several plant species, both grasses and legumes. The plants were first kept in the dark for forty-eight hours to deprive them of starch, whereupon they were placed in 10 per cent sugar solutions so that the ends of the stems were immersed while the leaves did not come into direct contact with the liquid. After a further twenty-four hours in the dark the leaves were cut off from the stems and dried and analysed separately. The drying was carried out in vacuo at $100^{\circ}$.

The results show that glucose and fructose are indeed easily converted into each other in plant tissue. The transformation takes place already in the stems, which is also the seat of sucrose synthesis. These reactions are not affected by an addition of 10 per cent toluene to the sugar solutions, and are only slightly retarded by a 0.05 molar potassium cyanide solution. There was evidence that in leaves part of the glucose disappears, possibly as a result of respiration. Under the conditions of the experiment, the synthesis of starch was very slight or nil. The stalks of horse-beans were found to contain much more invertase than the leaves.

The following experiment with horse-beans will illustrate the quantitative proportions in question. 20 plants were used for each determination. All values are computed on a 'residual-dry weight' basis.

$\begin{array}{lcccccc} & \begin{array}{c}\text { Dry } \\ \text { matter } \\ \text { Per cent }\end{array} & \begin{array}{c}\text { Total } \\ \text { soluble } \\ \text { sugars }\end{array} & \text { Glucose } & \text { Fructose } & \text { Sucrose } & \begin{array}{c}\text { In- } \\ \text { soluble } \\ \text { sugars }\end{array} \\ N \text { leaves } & 9 \cdot 05 & 7 \cdot 35 & 0 \cdot 7 & 4 \cdot 35 & 0 & 4 \cdot 3 \\ N \text { stems } & 6 \cdot 0 & 7 \cdot 1 & 0 \cdot 7 & 4 \cdot 6 & 0 & 10 \cdot 25 \\ D \text { leaves } & 7 \cdot 75 & 3 \cdot 9 & 0 & 2 \cdot 9 & 0 & 5 \cdot 6 \\ D \text { stems } & 5 \cdot 55 & 1 \cdot 9 & 0 & 1 \cdot 9 & 0 & 10 \cdot 85 \\ G \text { leaves } & 11 \cdot 65 & 17 \cdot 3 & 6 \cdot 2 & 3 \cdot 6 & 5 \cdot 1 & 7 \cdot 0 \\ G \text { stems } & 8 \cdot 0 & 26 \cdot 25 & 12 \cdot 2 & 7 \cdot 55 & 5 \cdot 15 & 11 \cdot 2 \\ F \text { leaves } & 13 \cdot 3 & 17 \cdot 2 & 2 \cdot 95 & 7 \cdot 05 & 6 \cdot 5 & 5 \cdot 3 \\ F \text { stems } & 8 \cdot 1 & 29 \cdot 15 & 8 \cdot 7 & 14 \cdot 8 & 7 \cdot 25 & 10 \cdot 6\end{array}$

( $N=$ normal plants, $D=$ plants kept in the dark for forty-eight hours, $G=$ plants kept in 10 per cent glucose solution for a further twenty four hours, and $F=$ plants kept in 10 per cent fructose solution for twenty-four hours)

Laboratory of the Foundation for

$$
\text { M. Nurmia (Nordlund). }
$$

Chemical Research,

Helsingfors, Finland Jan. 4.

${ }^{1}$ Virtanen, A. I., and Nordlund, M., Biochem. J., 28, 1729 ; 1934. 